\title{
Export, Industrial Productivity and International Competitiveness: A Case of Latvia
}

\author{
Astra Auziņa-Emsinga ${ }^{1}$, Velga Ozolinga ${ }^{2},{ }^{1-2}$ Riga Technical University
}

\begin{abstract}
The paper examines export, productivity and impact on the economy. The aim of the research is to analyse and estimate the exiting relations between exports of goods and services and labour productivity using the principles of inputoutput analysis and econometric methods. Special attention is devoted to Latvia's economy; however, in order to perform international comparison and reveal the existence of regional or global trends the data on several member states of the European Union are used. The results of estimations argue that the higher the real labour productivity (per employee and per hour worked), the higher the export volume will be. The results also confirm that the higher the value added is in output, the higher the export ratio will be despite the fluctuations over time.
\end{abstract}

Keywords: export, foreign trade, industry, efficiency, productivity, international competitiveness.

\section{INTRODUCTION}

Export is one of the key driving forces in any economy nowadays. Some countries are more export-oriented and the exports of goods and services can exceed the gross domestic product (GDP) of the economy, for example, in Luxembourg (where exports of goods and services accounted for $165 \%$ as a percentage of GDP) and Ireland (105\%) in 2011 according to the Eurostat data. At the same time, some countries are significantly less export-oriented, and export volume as a percentage of GDP does not exceed $30 \%$; for instance, in Greece (24\%), France (27\%), Italy (29\%). On average, in the European Union (EU) exports represent $44 \%$ of GDP. At present, Latvia's economy is notably more export-oriented compared to previous years, and the value of exports as a percentage of GDP increases from year to year; moreover, in 2011 it reached the highest value $-59 \%$.

Nowadays, it is admitted that the globalized world economy stimulates productivity and efficiency at sectoral and national levels and contrariwise. In 2011, Latvia's economy grew by $5.5 \%$; however, the main component and main driver was export volume that grew by $12.6 \%$ (in real terms). In the meantime, real labour productivity per hour worked grew by $14.5 \%$ in Latvia. This raises a question whether it is a general trend and observable in at least several countries and in various time periods or it is a temporary phenomenon.

The aim of the paper is to analyse and estimate the exiting relations between exports of goods and services and labour productivity. Special attention is devoted to Latvia's economy; however, in order to perform international comparison and reveal the existence of regional or global trends the statistical data on neighbouring countries such as Estonia and Lithuania are used, as well the data on several member states of the European Union (Austria, Slovakia etc.). The input-output (IO) data and analysis are used as the most appropriate and correct source of information and research method. However, in order to perform the general econometric analysis of existing relations in the economy, the statistical data of national accounts have been used.

The paper tests the stated hypothesis that higher export activity (real export of goods and services; ratio of exports to gross national product (GDP)) leads to higher industrial efficiency in a producing (also exporting) country (in Latvia).

In the research, databases of national statistical office [1], Eurostat - national accounts etc. [2] and IO [3], and International Monetary Fund ([4]) and WIOD [5] are extensively used.

\section{REVIEW OF LITERATURE}

Industrial efficiency and productivity taking into account the impact on sales (including foreign trade) analysed under the input-output analysis have been considered by various authors. However, the authors have focused on so diverse aspects (offshoring [6], natural disasters [7], and transport [8] etc.), it is observed that there are no reports on the study that examines the relations and economic conditions observed in Latvia (sharp economic growth for years followed by the one of the fastest economic recessions; sharp and stable recovery of exporting activity after an economic crisis etc.).

\section{RESEARCH METHODS}

In the study, the econometric and statistics methods have been used, as well principles of input-output (IO) analysis. The applied methodology includes the computation of a set of ratios that characterizes whether one (export, productivity or competitiveness) or several aspects. The authors stress that each applied indicator represents specific issues that other indicators cannot cover, and none of these indicators cover all the aspects. Hence, only a system of indicators is the most appropriate in the research of export, productivity and competitiveness analysed together.

The following indicators are calculated on the basis of National Accounts (NA) and IO table data:

1) exports of goods and services (as a percentage of GDP),

2) real export growth rate $(\%)$,

3) gross labour productivity,

4) ratio of value added to compensation of employees

5) ratio of value added to unit spent on labour,

6) labour input coefficient,

7) ratio of value added to output;

8) export dependency.

In addition to the above-mentioned indicators that are computed within the framework of research, several important additional NA indicators are used - for instance, real labour productivity (per person and per hour worked). 
In order to reveal the importance of current level of export orientation or dependency of total economy and the dynamics (towards more extensive export-oriented economy or contrariwise), the ratio of exports of goods and services to GDP as a percentage is calculated.

$$
\text { EXP }-\%_{t}=\frac{\operatorname{EXF}_{r}}{\operatorname{GDP}}
$$

where EXP_\% $\%_{t}$ - exports of goods and services (nominal) in the period of time $t$;

$\mathrm{GDP}_{\mathrm{t}}-\mathrm{GDP}$ in the period of time $\mathrm{t}$;

Real export growth rate is computed and applied to the research in order to reveal the dynamics of real impact of export (without price effect). Very valuable element of application of this indicator to the analysis is comparison with the average growth rate of the economy (real GDP growth rate) and the real export growth rate in other countries that have close economic links with the national economy. In the study, the data representing Estonia and Lithuania, as well the data on the EU-27 are used.

The indicator of gross labour productivity in a sector is calculated by the following formula:

$$
p_{t, 5}=\frac{x_{i s}}{f_{i 5}}
$$

where pi - the gross labour productivity of sector $i$ in the period of time $t$;

$\mathrm{xi}$-the gross output of sector $\mathrm{i}$ in the period of time $\mathrm{t}$;

ei - the number of employed persons in sector $\mathrm{i}$ in the period of time $t$.

The authors admit that this solution is trade-off of theoretical and data endowment. For instance, Belegri-Roboli et.al [9] analysed the labour productivity and working time changes in Greece employment measured in hours worked. However, this approach (hours worked) and employment measured in full-time equivalent are not applicable to this case due to the lack of data at an appropriate level of disaggregation and length of time-series.

The ratio of value added to compensation of employees $p v \_u_{i, t}$ is calculated by the following formula:

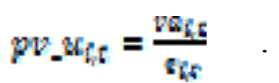

The ratio of value added to compensation of employees is an important indicator that embodies the ability of one unit spent on labour to generate one unit of value added. As value added and, consequently, gross domestic product are major economic outcome estimation indicators, a higher value of this ratio indicates higher potential to generate greater value added. In general, the greater the value added in the economy in general and per capita, the better it is. Consequently, the higher value of this ratio is, the better it is for the economy.

In order to reveal the economic effect of labour to generate value added, the modified ratio - ratio of value added to unit spent on labour $p v_{-} u_{i, t}{ }^{*}-$ is calculated by the following formula:

$$
w_{-} w_{i t}=\frac{v a_{\xi 5}}{w_{h s}}
$$

This indicator shows the extent of value added (in money terms) generated by one unit spent on labour.

Labour input coefficient $l_{i, t}$ of sector $\mathrm{i}$ is computed by the following formula:

$$
\varepsilon_{i c}=\frac{\varepsilon_{l s}}{x_{k s}} .
$$

Ratio of value added to output (share of value added in sectoral output) $v_{i, t}$ is computed by the following formula:

$$
v_{i 5}-\frac{v_{a_{i 5}}}{x_{i 5}}
$$

In fact, the higher the share of value added in sectoral cost structure, the better it is for the economy. Industries are classified by the technologies applied to high value-added industries (or high-technology industries), taking into account the share of value added in sectoral production.

Export dependency ratio shows dependency of certain industry on economic activity abroad (in an importing country and related industries internationally) and foreign demand (volume, structure, preferences, trends etc.). In literature [10], several similar concepts are used.

In the research, export dependency ratio exp_dep ext $_{\text {in }}$ is computed by the following formula proposed by the author in [10], but it is adopted for multi-sectoral analysis on the basis of input-output table data rather than industrial production statistical data.

$$
\exp _{-} d e p_{i, t}=\frac{\exp _{i, t}}{x_{i, t}}
$$

Economic activity is analysed according to the level of sectoral disaggregation of NACE classification Rev.1.1 regarding major (1-digit disaggregation) and more sophisticated sectoral disaggregation (3-digit disaggregation). Results of computation in sectoral level are compared with Estonia's and Lithuania's sectoral results, as well as dynamics is analysed.

\section{ANALYSIS AND RESULTS}

In the research, two IO tables are used - of 2004 and 2007 (at current prices, national currency), as well as annual timeseries of NA indicators (at current prices and at constant prices (volume), EUR) and auxiliary indicators to NA (as labour productivity, real labour productivity per hour worked) (20002011) (at constant prices (volume)). Economic activity is analysed according to the level of sectoral disaggregation of NACE classification Rev.1.1 (as input-output tables) and Rev.2 (as latest National Accounts). As economic performance of Latvia is frequently compared to that of Estonia and Lithuania, the international comparison is performed according to the methodology and data of IO tables of these countries.

The data source is the Eurostat database - IO tables [2]; National Accounts aggregates and employment by 60 branches (NACE Rev1.1), auxiliary indicators to National Accounts [3]. 
It is worth stressing that the World Input-Output Database (WIOD) project finished in early 2012 and there are available sets of input-output tables for almost all countries all over the world, including Latvia [5], (mostly annual tables of 19952009). This valuable, but not prepared by national statistical office, information is also introduced in the research. However, in order to insure the data comparability and for other reasons, all input-output tables included in the WIOD are with common sectoral classification and sectoral disaggregation ( $34 * 34$ industries; industry-by-industry tables), but this sectoral classification is comparable with the EU and is less sectorally disaggregated. In the research, data of Latvia's input-output data of 2000-2009 are used for the computation of ratios and for an analysis.

In the study, main attention is devoted to the following NA and other indicators: exports of goods and services, gross domestic product, value added.

Latvia's economy has medium high export influence if exports impact on the size of national economy is analysed. Within the EU, some countries are more export-oriented and the exports of goods and services can exceed the gross national product (GDP) of the economy, for example, in Luxembourg, (where exports of goods and services accounted for $165 \%$ as a percentage of GDP ) and Ireland (105\%) in 2011 according to the Eurostat [2] data (See Table 1).

TABLE 1

EXPORTS OF GOODS AND SERVICE (AS \% OF GDP)

\begin{tabular}{lccc}
\hline Country & 2000 & 2011 & $\begin{array}{c}\text { Change in 2000--2011 } \\
\text { (\% points) }\end{array}$ \\
\hline EU-27 & 35.9 & 43.6 & 7.7 \\
Lithuania & 44.5 & 78.0 & 33.5 \\
Slovakia & 70.4 & 89.1 & 18.7 \\
Slovenia & 53.7 & 72.3 & 18.6 \\
Hungary & 74.6 & 92.5 & 17.9 \\
Poland & 27.1 & 44.8 & 17.7 \\
Latvia & $\mathbf{4 1 . 9}$ & $\mathbf{5 9 . 3}$ & $\mathbf{1 7 . 4}$ \\
Germany & 33.4 & 50.1 & 16.7 \\
Bulgaria & 50.5 & 66.5 & 16.0 \\
Luxembourg & 150.0 & 164.7 & 14.7 \\
the Czech Republic & 60.9 & 74.9 & 14.0 \\
the Netherlands & 70.1 & 82.7 & 12.6 \\
Austria & 46.2 & 57.3 & 11.1 \\
Malta & 90.6 & 99.0 & 8.4 \\
Ireland & 97.3 & 105.6 & 8.3 \\
Estonia & 84.6 & 92.7 & 8.1 \\
Denmark & 46.5 & 53.8 & 7.3 \\
Belgium & 78.1 & 85.0 & 6.9 \\
Portugal & 28.9 & 35.5 & 6.6 \\
Romania & 32.8 & 38.3 & 5.5 \\
the United Kingdom & 27.7 & 32.5 & 3.6 \\
Sweden & 46.5 & 50.1 &
\end{tabular}

\begin{tabular}{lccc} 
Italy & 26.8 & 28.8 & 2.0 \\
Spain & 29.1 & 30.1 & 1.0 \\
Greece & 24.9 & 24.0 & -0.9 \\
France & 28.8 & 27.0 & -1.8 \\
Finland & 43.6 & 40.7 & -2.9 \\
Cyprus & 56.1 & 43.3 & -12.8 \\
\hline
\end{tabular}

Source: the authors' calculations based on the Eurostat database [3]

At the same time, some member states are less exportoriented and the export volume as a percentage of GDP does not exceed 30\%; for instance, in Greece (24\%), France (27\%), Italy $(29 \%)$. On average, in the European Union (EU) exports account for $44 \%$ of GDP (see Fig. 1).

At present, Latvia's economy is notably more exportoriented compared to previous years, and the value of exports as a percentage of GDP increases from year to year; moreover, in 2011 it reached the highest value $-59 \%$ (See Fig. 1.).

Table 1 shows the significance of export in 2000 and 2011, as well as the change (in percentage points in the time period of 2000-2011). It is noticeable that change in percentage points of relative export significance in Latvia is one of the largest in the EU. The largest increase was observable only in Lithuania, Slovakia, Slovenia, Hungary, and Poland.

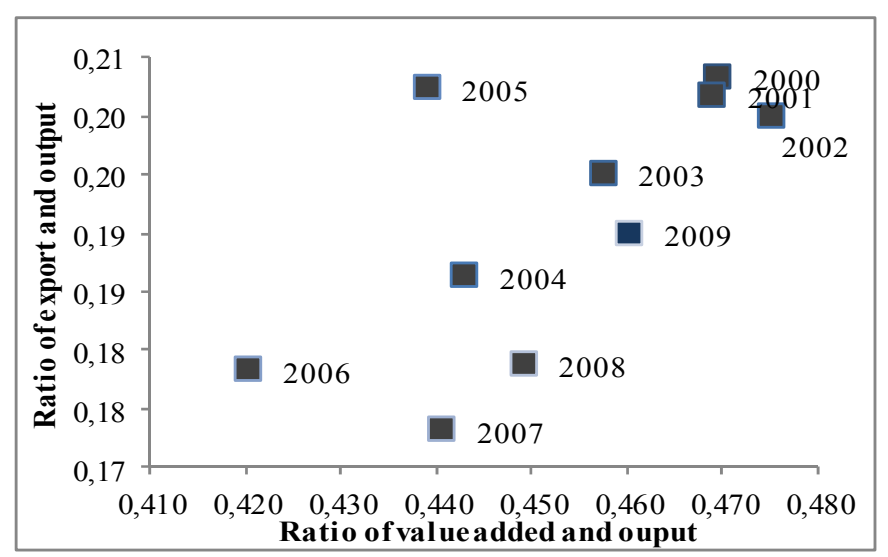

Fig. 1. Dynamics of exports of goods and services (percentage of GDP) in Latvia and the EU-27, 2000-2011.

Source: the authors' calculations based on the Eurostat database [3].

It is evident from dynamics of exports of goods and services in 2000-2011 that the most notable increase (from 42.5 to 59.3) took place in 2009-2011 - during the economic crisis period (see Fig. 1). Thus, it verifies the notion that export is a key driving force in economic recession, and it is one of the factors that ended recession and had a positive effect on national economy to grow.

However, Latvia's exporting capacity shows fascinating results - since 2000 only in one year Latvia's real export grew with a lower rate than in the EU on average (see Fig. 2). The exception is the year of 2009, when Latvia's economy declined by $17.7 \%$ and export decreased by $14.1 \%$. 


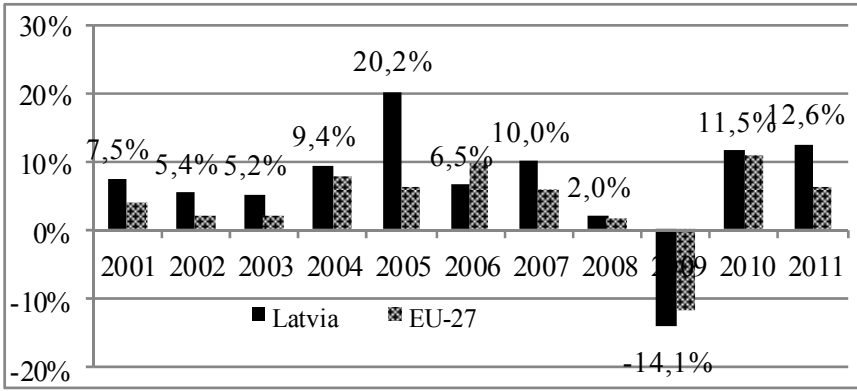

Fig. 2. Real export growth rate in Latvia and the EU-27, 2001-2011.

Source: the authors' calculations based on the Eurostat database [3].

The research includes the econometric estimation of strength of relationships between exports of goods and services, real labour productivity (per hour worked) and productivity (per employee; EU-27=100) in 2000-2011. The results of relationship analysis show a strong correlation:

a) between labour productivity (per employee; EU-27=100) (lab_prod) and real exports (coefficients of correlation $\left(\mathrm{R}^{2}=0.96\right)$; and

b) between real labour productivity per hour worked in EUR (r_lab_prod) and real exports $\left(\mathrm{R}^{2}=0.82\right)$ (See Fig. 3)

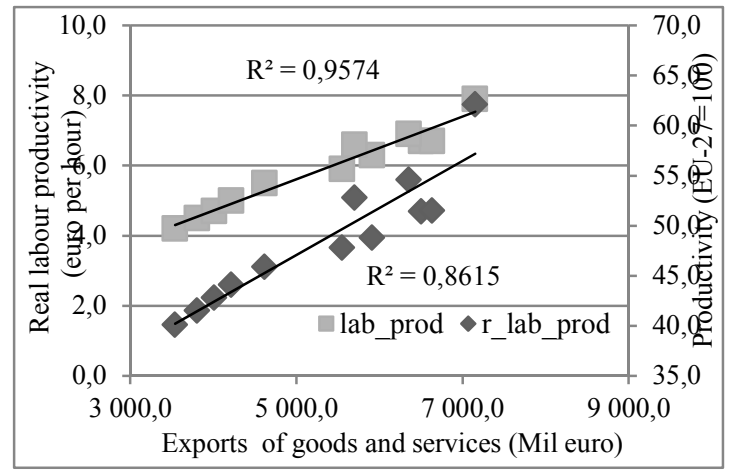

Fig. 3. Labour productivity, real labour productivity and real exports. Source: the authors' calculations based on the Eurostat database [3].

The results of the above analysis argue that the higher the labour productivity is, the higher the exports will be. The results of relationship analysis between a real export growth rate and a GDP growth rate show a medium strong correlation (see Fig. 4). The results demonstrate that the higher the export growth rate is, the higher the national economic growth will be. However, Latvia's economy is an import dependent economy since many resources or materials etc. used in the production of other products (intermediate inputs) or as final demand products should be imported, and in order to ensure the additional increase in economic activity due to additional export, additional imports are required. The results of relationship analysis between a real import growth rate and a GDP growth rate show a medium strong correlation (see Fig. 5).

The estimation results argue that the higher the exporting activity is, the higher the volume of economic activity will be, and the higher the import growth rate will be.

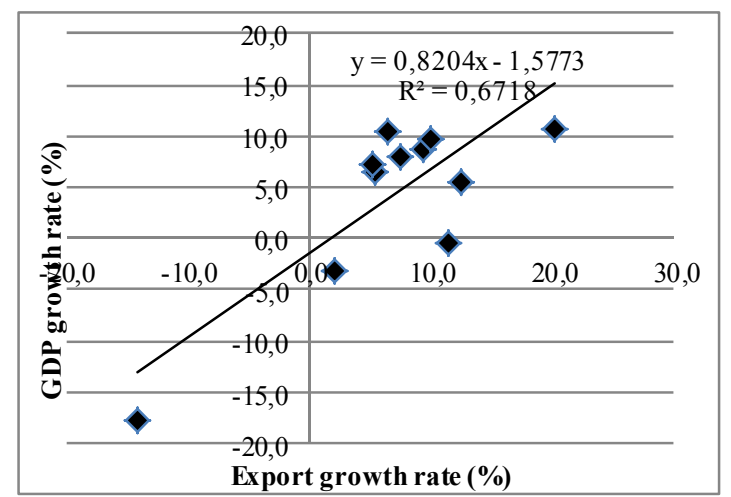

Fig. 4. Export growth rate (\%) and GDP growth rate (\%) in 2001-2011 in Latvia.

Source: the authors' calculations based on the Eurostat database [3].

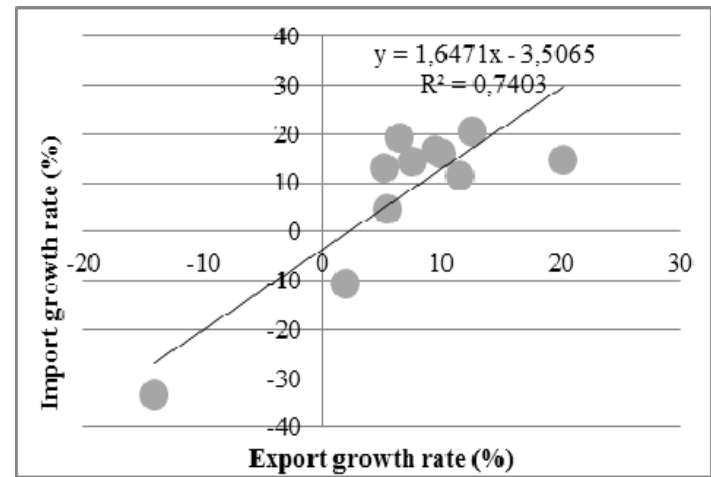

Fig. 5. Export growth rate (\%) and import growth rate (\%) in 2001-2011 in Latvia.

Source: the authors' calculations based on the Eurostat database [3].

Table 2 shows the results of ratio analysis - ratio of value added to compensation of employees, ratio of value added to unit spent on labour, and labour input coefficient. Calculated values of ratio of value added to compensation of employees $p v \_u_{i, t}$ for 2004 and 2007 show that one unit spent on labour generated smaller total output in 2007 rather than it was on average in the economy in $2004-1.9$ and 2.3 money units, respectively. Latvia's economy is diverse and, hence, the values of this indicator measuring industrial efficiency vary significantly $(0.7 \div 8.0$ in 2004 and $7.2 \div 1.1$ in 2007). The industries with the highest values are service sectors such as real estate services (NACE Rev.1.1 code: 70) - 8.0 - and supporting and auxiliary transport activities, activities of travel agencies (63) - 6.0 in 2004. However, in 2007 -real estate activities (70) - 7.2; fishing (05) - 5.1; and renting of machinery and equipment (71) - 5.0.

Industrial sector overall shows medium performance, the highest value is in manufacture of basic metals (27) - 3.4; at the same time, manufacture of textiles (17) - 1.1; manufacture of motor vehicles, trailers and semi-trailers (34) - 1.1; manufacture of electrical machinery and apparatus n.e.c. (31) -0.7 ; together with public service sector, such as health (85) -1.2 and education (80) - 1.1, show the lowest values in 2004. However, as the year of 2007 was the last positive real economic growth year, it is also noticeable by this indicator. Several pre-cyclic industries, such as construction $(45)-1.3$, showed very low values. 
TABLE 2

SECTORAL EFFIENCY AND LABOUR INPUT COEFFCIENTS

\begin{tabular}{|c|c|c|c|c|c|c|c|}
\hline \multirow[b]{2}{*}{ Industry (NACE Rev.1.1. Code) } & & \multicolumn{3}{|c|}{2004} & \multicolumn{3}{|c|}{2007} \\
\hline & & $p v \_u_{i, t}$ & $p v \_u_{i, t^{*}}$ & $l_{i, \mathrm{t}}$ & $p v \_u_{i, t}$ & $p v \_u_{i, t^{*}}$ & $l_{i, \mathrm{t}}$ \\
\hline Agriculture, hunting and related service activities & 01 & 5.8 & 6.9 & 0.07 & 2.5 & 2.8 & 0.14 \\
\hline Forestry, logging and related service activities & 02 & 2.4 & 2.7 & 0.13 & 5.0 & 6.0 & 0.09 \\
\hline Fishing & 05 & 2.2 & 2.6 & 0.13 & 5.1 & 7.5 & 0.09 \\
\hline Mining of coal and lignite; extraction of peat & 10 & 1.7 & 2.1 & 0.22 & 1.9 & 2.2 & 0.20 \\
\hline Other mining and quarrying & 14 & 4.5 & 5.4 & 0.18 & 2.3 & 2.5 & 0.19 \\
\hline Manufacture of food products and beverages & 15 & 1.8 & 2.2 & 0.12 & 1.7 & 1.9 & 0.14 \\
\hline Manufacture of textiles & 17 & 1.1 & 1.4 & 0.19 & 1.4 & 1.6 & 0.22 \\
\hline Manufacture of wearing apparel & 18 & 1.8 & 2.1 & 0.21 & 1.3 & 1.5 & 0.26 \\
\hline Manifacture of luggage, handbags, footwear & 19 & 1.4 & 1.6 & 0.18 & 1.5 & 1.7 & 0.23 \\
\hline Manufacture of wood and of products of wood & 20 & 1.8 & 2.2 & 0.12 & 1.7 & 1.9 & 0.16 \\
\hline Manufacture of pulp, paper and paper products & 21 & 2.0 & 2.5 & 0.11 & 1.8 & 2.0 & 0.17 \\
\hline Publishing, printing and reproduction of recorded media & 22 & 1.8 & 2.1 & 0.19 & 1.6 & 1.8 & 0.22 \\
\hline Manufacture of chemicals and chemical products & 24 & 1.7 & 2.1 & 0.20 & 1.7 & 1.9 & 0.22 \\
\hline Manufacture of rubber and plastic products & 25 & 1.9 & 2.3 & 0.11 & 1.7 & 2.0 & 0.15 \\
\hline Manufacture of other non-metallic mineral products & 26 & 2.1 & 2.5 & 0.10 & 1.8 & 2.1 & 0.16 \\
\hline Manufacture of basic metals & 27 & 3.4 & 4.2 & 0.07 & 2.3 & 2.6 & 0.10 \\
\hline Manufacture of fabricated metal products & 28 & 1.7 & 2.0 & 0.16 & 2.0 & 2.3 & 0.17 \\
\hline Manufacture of machinery and equipment n.e.c. & 29 & 1.7 & 2.1 & 0.21 & 2.0 & 2.3 & 0.22 \\
\hline Manufacture of electrical machinery and apparatus n.e.c. & 31 & 0.7 & 0.9 & 0.15 & 1.8 & 2.1 & 0.20 \\
\hline Manufacture of motor vehicles, trailers and semi-trailers & 34 & 1.1 & 1.3 & 0.14 & 1.7 & 1.9 & 0.15 \\
\hline Manufacture of other transport equipment & 35 & 1.2 & 1.5 & 0.22 & 1.5 & 1.7 & 0.21 \\
\hline Manufacture of furniture; manufacturing n.e.c. & 36 & 1.9 & 2.2 & 0.21 & 2.6 & 3.0 & 0.12 \\
\hline Electricity, gas, steam and hot water supply & 40 & 2.5 & 3.1 & 0.14 & 3.1 & 3.8 & 0.10 \\
\hline Collection, purification and distribution of water & 41 & 1.4 & 1.8 & 0.28 & 3.4 & 4.2 & 0.21 \\
\hline Construction & 45 & 2.2 & 2.6 & 0.11 & 1.3 & 1.4 & 0.17 \\
\hline Sale, maintenance and repair of motor vehicles, fuel & 50 & 3.0 & 3.6 & 0.17 & 2.3 & 2.6 & 0.23 \\
\hline Wholesale trade & 51 & 3.6 & 4.2 & 0.17 & 2.1 & 2.4 & 0.23 \\
\hline Retail trade & 52 & 2.1 & 2.5 & 0.34 & 1.5 & 1.7 & 0.37 \\
\hline Hotels and restaurants & 55 & 2.4 & 2.9 & 0.21 & 1.4 & 1.5 & 0.33 \\
\hline Land transport; transport via pipelines & 60 & 1.5 & 1.9 & 0.19 & 2.2 & 2.6 & 0.19 \\
\hline Supporting and auxiliary transport activities & 63 & 6.0 & 7.2 & 0.11 & 2.0 & 2.3 & 0.11 \\
\hline Post and telecommunications & 64 & 3.5 & 4.3 & 0.16 & 2.9 & 3.4 & 0.17 \\
\hline Financial intermediation & 65 & 2.9 & 3.6 & 0.18 & 2.5 & 3.1 & 0.25 \\
\hline Insurance and pension funding, except compulsory social security & 66 & 1.2 & 1.5 & 0.36 & 1.6 & 1.9 & 0.32 \\
\hline Activities auxiliary to financial intermediation & 67 & 1.3 & 1.4 & 0.67 & 2.2 & 2.6 & 0.24 \\
\hline Real estate activities & 70 & 8.0 & 9.6 & 0.09 & 7.2 & 8.1 & 0.08 \\
\hline Renting of machinery and equipment & 71 & 2.9 & 3.5 & 0.22 & 5.0 & 5.7 & 0.11 \\
\hline Computer and related activities & 72 & 1.7 & 2.1 & 0.30 & 1.3 & 1.5 & 0.38 \\
\hline Research and development & 73 & 1.2 & 1.4 & 0.45 & 1.3 & 1.7 & 0.33 \\
\hline Other business activities & 74 & 1.8 & 2.2 & 0.26 & 1.5 & 1.6 & 0.30 \\
\hline Public administration and defence; compulsory social security & 75 & 1.4 & 1.8 & 0.41 & 1.5 & 2.0 & 0.46 \\
\hline Education & 80 & 1.1 & 1.4 & 0.74 & 1.1 & 1.4 & 0.71 \\
\hline Health and social work & 85 & 1.2 & 1.4 & 0.43 & 1.2 & 1.5 & 0.56 \\
\hline Sewage and refuse disposal, sanitation and similar activities & 90 & 1.5 & 1.8 & 0.35 & 1.3 & 1.5 & 0.36 \\
\hline Activities of membership organisation n.e.c. & 91 & 1.3 & 1.6 & 0.20 & 1.2 & 1.5 & 0.31 \\
\hline Recreational, cultural and sporting activities & 92 & 2.0 & 2.3 & 0.28 & 1.7 & 2.0 & 0.33 \\
\hline Other service activities & 93 & 3.7 & 4.3 & 0.20 & 1.8 & 2.0 & 0.27 \\
\hline Total & & 2.3 & 2.7 & 0.20 & 1.9 & 2.2 & 0.22 \\
\hline
\end{tabular}

Source: the authors' calculations based on the Eurostat database [3]. Sectors 11, 12, 13, 16, 23, 30, 32, 33, 37, 61, 62 are excluded due to lack of data. 
If analysed by industries, the results of a certain industry even in the short run reveal the fact that this value can notably fluctuate due to changes in technologies, specialisation within a certain industry or statistical coverage. Hence, this indicator cannot be used as the only general indicator representing efficiency and indirect competitiveness of industry in domestic and international markets.

During the fast economic growth period (2004-2007), when Latvia's economy boosted in many industries, wages and salaries grew faster than the output (or productivity); thus, industries lost their competitiveness in comparison with historical positions in the market. Ratio of value added to unit spent on labour $p v \_u_{i, t} *$ clearly represents the economic effect of one unit spent on wages and salaries in a certain industry and period of time. The analysis of calculated values (see Table 2) indicates the same trend as a ratio of value added to compensation of employees in the industries under analysis. Industries have weakened their positions and show lower efficiency of used resources (in this case, labour directly). As these two indicators are closely related by content, the similar facts are observable regarding the industries with highest and lowest values.

Labour input coefficient shows the labour intensity of industries or economy. It is a modern trend of latest decades that capital (through investments) replaces labour in costs structure. Additional resources spent on purchases, maintenance, improvement, upgrading the technology used result in higher capital input ratio and higher capital intensity.

The analysis of IO tables shows that labour input coefficients fluctuate significantly in various branches of economy - from 0.08 (real estate services (70)) to 0.71 (education (80)) in 2007. However, from 2004 to 2007 the value of labour input coefficient increased from 0.20 to 0.22 . It is worth stressing that in Latvia values of labour input coefficient are relatively low if compared to other EU member states (for instance, in 2007 in Austria (EU economy with one of the lowest unemployment rates) -0.26 ; in Lithuania -0.25 and in Estonia - 0.23 - as in neighbouring countries; however, in Slovakia (close to Austria geographically and by economic relations) - 0.16). Such an increase does not directly show a shift of the economy towards labour-intensive and low-value added economy.

This inaccuracy is mainly caused by the values of 2005 that show unusual state of the economy - significantly higher export dependency rate (than in 2004) but with the same value added to a level of output ratio.

In conclusion of the research, sectoral efficiency and export dependency are analysed to reveal the existing relationships on the basis of WIOD data. The ratio of value added to output and ratio of export to output (export dependency rate) are calculated for total economy and by 34 industries.

The existing relationship is observable visually (see Fig. 6). However, the estimation analysis demonstrates that there is a relatively weak relationship between a ratio of value added to output and export dependency rate $\left(\mathrm{R}^{2}=0.45 ; 2000-2009\right)$.

As the focus of the research is placed on industrial activity, results of two of major manufacturing industries (manufacture of food, beverages and tobacco $(15 ; 16)$ and manufacture of wood and products of wood) are presented in more detail.

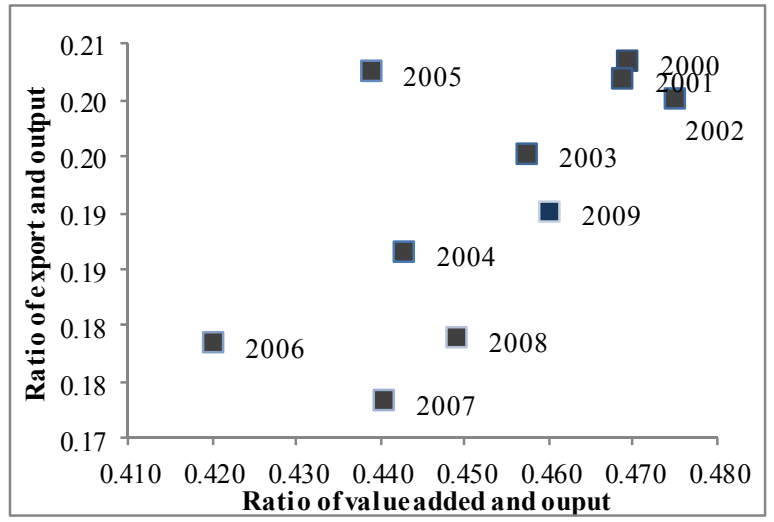

Fig. 6.Value added and export dependency in Latvia 2000-2009 (ratios). Source: the authors' calculations based on WIOT database [5].

The estimation results of industry of manufacture of food, beverages and tobacco show that a strong relationship is not observable $\left(\mathrm{R}^{2}\right.$ is below 0.4$)$. However, at the same time, due to specifics of the industry (as strong orientation towards domestic market, caused by high transportation and storage costs, legislation and other regulation requirements, preferences etc.), it is observable that this has a slight impact on an increase in value added per unit of output in this industry.

The estimation results of industry of manufacture of wood and products of wood are similar - a strong relationship is not detected $\left(\mathrm{R}^{2}\right.$ is below 0.4 ) (See Fig. 7). However, this industry has one of the highest export dependency rates as a large portion of output is exported.

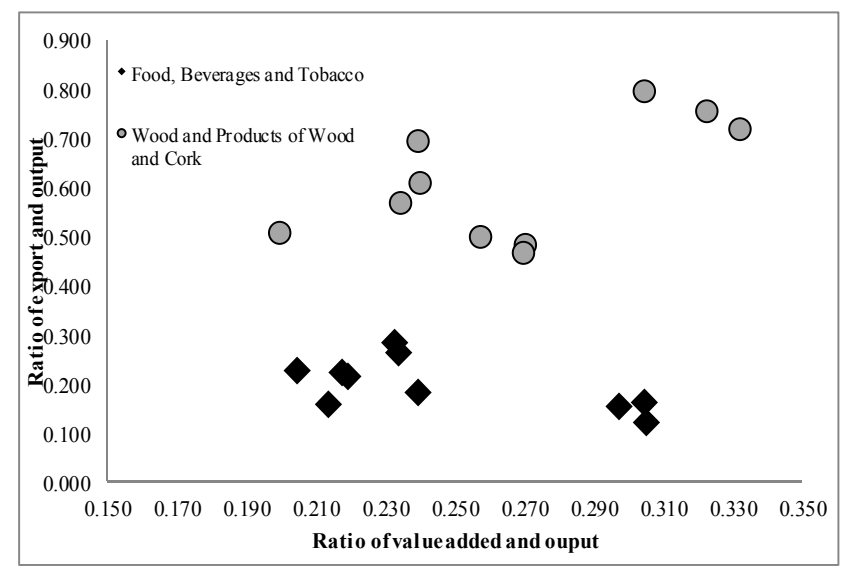

Fig. 7. Value added and export dependency in Latvia 2000-2009 - two industries (ratios).

Source: the authors' calculations based on the Eurostat database [5].

Thus, it is concluded that orientation towards export (foreign) market may and in many cases stimulates an increase in economic performance (including productivity improvements); however, in the industry within economy there are many important factors that have a greater influence than exporting activity (legislation, production specifics, transportation and storage costs etc.).

\section{CONCLUSION}

The findings about the Latvia's economic activity and real productivity show that since 2000 exports of goods and services (at constant prices) have doubled from 3.5 to 7.2 
billion EUR in 2011 - at the same time, the ratio of exports on GDP has also increased significantly - from $41.9 \%$ to $59.3 \%$ indicating the actual shift in exporting in Latvia.

It is also concluded that labour input coefficients have not changed by such an extent and difference from the level in neighbouring countries is relatively low. Productivity represents efficiency of used technologies and labour in the economy.

The results of estimations argue that the higher the real labour productivity (per employee and per hour worked) is, the higher the exports will be. The results also confirm that the higher the value added is in output, the higher the export ratio will be despite the fluctuations over time.

The growth of productivity is also observed and, from a theoretical point of view, it is favourable for the economy. However, it is worth analysing the sectoral level in order to obtain more accurate and truthful results. The results of two leading manufacturing industries - manufacture of food and manufacture of wood products - show various results of relationships between a ratio of value added to output and a ratio of exports to output. The results confirm that the existing sectoral relationships between the above-mentioned ratios vary significantly among industries displaying competitiveness.

On the basis of research, it is concluded that WIOD data are a valuable source for sectoral and inter-industrial analysis and modelling; however, they cannot replace a complete set of input-output tables (required by Eurostat) that include such tables as margin matrix, taxes on products and other matrices. It is recommended using these data if international comparison, analysis or modelling are performed in order to ensure comparability and consistency.

\section{REFERENCES}

[1] Central Statistical Bureau of Latvia. Database. [Online]. Available: http://www.csb.gov.lv [Accessed: August 2, 2012].

[2] Eurostat (2012a) ESA 95 Supply Use and Input-Output tables. [Online]. Available: http://epp.eurostat.ec.europa.eu/portal/page/portal/statistics/ search_database [Accessed: August 2, 2012].

[3] Eurostat (2012b) National accounts (including GDP) [Online]. Available: http://epp.eurostat.ec.europa.eu/portal/page/portal/statistics/ search database [Accessed: August 2, 2012]

[4] International Monetary Fund (IMF) World Economic Outlook Databases Available: http://www.imf.org/external/data.htm [Accessed: August 30, 2012]

[5] World Input-Output tables Database Available: http: http://www.wiod.org/database/iot.htm [Accessed: September 6, 2012].
[6] B. Michel, (2011), Direct and indirect productivity gains from offshoring, 19th International Input-Output Conference, Alexandria, USA, 13-17 June 2011.-

[7] J. R. Santos, (2011), An input-output framework for assessing hurricane impact on regional workforce productivity, 19th International InputOutput Conference, Alexandria, USA, 13-17 June 2011.

[8] T. Tantirigama, J. Leung, (2011) Contribution of transport to economic growth and productivity in New Zealand, 19th International InputOutput Conference, Alexandria, USA, 13-17 June 2011.

[9] A. Belegri-Roboli, M. Markaki \& P. G. Michaelides, (2011): LABOUR PRODUCTIVITY CHANGES AND WORKING TIME: THE CASE OF GREECE , Economic Systems Research, 23:3, 329-339. http://dx.doi.org/10.1080/09535314.2011.595777

[10] A. Auzina, "Export Dependency of Latvia's Manufacturing Sector." Economics \& Business, vol. 21, p.7-12, 2011. Business Source Complete, EBSCOhost [accessed September 5, 2012].

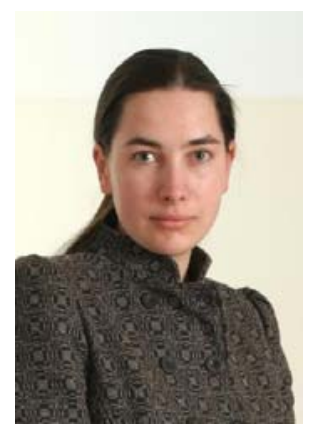

Astra Auziņa-Emsiṇa holds a $\mathrm{PhD}$ Degree in Economics (Dr.oec.), Riga Technical University, 2008. The author is an Assistant Professor since 2009 and Researcher since 2006 at the Faculty of Engineering Economics and Management of Riga Technical University. The author has been involved in research devoted to economic modelling and sectoral interlinkages since 2004 and has developed several multisectoral macroeconomic models (INFORUM type model and CGE models for Latvia's economy). The research interests are the following: macroeconomic modelling, intersectoral relations, industrial development,

economic development and sectoral competitiveness.

She is a Member of International Input-Output Association, Member and Co-founder of the Association of Latvian Young Scientists, Member of the Association of Latvian Econometrists.

Address: Kalnciema Str. 6 - 216, LV-1048, Latvia.

E-mail: astra.auzina-emsina@rtu.lv

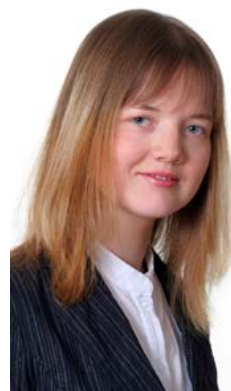

Velga Ozolina holds a PhD Degree in Economics (Dr.oec.), Riga Technical University, Latvia, 2009.

The author is an Assistant Professor since 2010 and Researcher since 2006 at the Faculty of Engineering Economics and Management of Riga Technical University. The author is involved in macroeconomic modelling and is elaborating a macro-econometric model of Latvia. Research interests include different issues of economic analysis, macroeconomic modelling and external trade of Latvia.

She is a Member of the Association of Latvian Econometrists. The author's Doctoral Thesis "Elaboration of Latvia's Macroeconometric Model and Its Application for Economic Analysis and Forecasting" is awarded as the Research of Young Scientist of 2010 in the group of Doctoral Theses by the Association of Latvian Econometrists. Address: Kalnciema Str. 6 -216, LV-1048, Riga, Latvia. E-mail: velga.ozolina@rtu.lv

Astra Auziṇa-Emsina. Velga Ozoliṇa. Latvijas eksports, nozaru produktivitāte un starptautiskā konkurētspēja

Rakstā tiek analizēts eksports, nozaru produktivitāte un to ietekme uz ekonomiku. Pētījuma mērkis ir analizēt un novērtēt pastāvošās sakarības starp preču un pakalpojumu eksportu un darbaspēka produktivitāti, izmantojot input-output analīzes principus un ekonometriskās metodes. Jāatzīmē, ka galvenais uzsvars pētījumā tiek likts uz Latvijas ekonomiku, tomēr, lai veiktu starpvalstu salīdzinājumu un atklātu pastāvošās tendence reǵionu vai pasaules mērogā, dati par kaiminvalstīm (Lietuvu un Igauniju), kā arī vairākām Eiropas Savienības valstīm tiek izmantoti. Pētījumā veikto ekonometrisko novērtējumu rezultāti apliecina, ka pastāv sakarība, t.i., jo augstāka reālā darbaspēka produktivitāte (rēkinot uz vienu nodarbināto un uz vienu nostrādāto stundu), jo lielāks ir eksports. Rezultāti arī apstiprina, ka būtisks ir pievienotās vērtības īpatsvars izlaidē, jo pastāv spēcīga sakarība starp pievienotās vērtības īpatsvaru izlaidē un eksporta atkarības līmeni (eksporta un izlaides attiecību) - jo augstāks pievienotās vērtỉbas īpatsvars, jo augstāka eksporta atkarība. Pētījumā būtisks elements ir nodrošinājums ar aktuāliem un salīdzināmiem statistikas datiem, šim nolūkam pētījuma veikšanai ir izmantoti dažādi datu avoti, tai skaitā Centrālās statistikas pārvaldes, Eurostat, World Input-Output Database dati.

Астра Аузиня-Эмсиня. Велга Озолиня. Экспорт, продуктивность производства и международная конкурентоспособность: опыт Латвии В данной статье анализируется экспорт, отрослевая производительность и их влияние на экономику. Целью исследования является анализ и оценка отношений между экспортом товаров и услуг и производительностью труда с использованием эконометрических методов и принципов анализа баланса межотраслевых связей (input-output).Следует отметить, что в центре внимания исследования находится латвийская экономика, однако, для проведения международного сравнения и выявления текуших тенденций регионального или глобального масштаба, использовались данные соседних стран (Эстонии и Литвы), а также ряда стран Европейского Союза. Результаты проведённых расчётов показывают, что существует зависимость, чем выше реальная производительность труда (в расчёте на сотрудника за час работы), тем выше экспорт. Полученные результаты также подтверждают, что важен удельный вес добавленной стоимости в выпуске продукции и услуг, потому что существует сильная зависимость между удельным весом добавленной стоимости в выпуске продукции и услуг и зависимости от экспорта (соотношение экспорта и выпуска продукции и услуг) - чем выше удельный вес добавленной стоимости, тем выше экспортная зависимость. Важным элементом исследования является подготовка актуальных статистических данных. В исследовании использовалсь данные различных источников, в том числе Центрального статистического бюро ЛР, Евростата, данные всемирной базы данных баланса межотраслевых связей (World Input-Output Database). 